Vol. 2, No. 2, 2021

Mykola Zhuk, Halyna Pivtorak, Ivanna Gits

Lviv Polytechnic National University

12, Bandery Str., Lviv, 79000, Ukraine

(C) M. Zhuk, H. Pivtorak, I. Gits, 2021

https://doi.org/ 10.23939/tt2021.02.011

\title{
ASSESSMENT OF SUSTAINABILITY OF THE LVIV CITY TRANSPORT SYSTEM ACCORDING TO THE INDICATOR OF ACCESSIBILITY
}

\begin{abstract}
Summary. Transport accessibility of the territory determines the possibility of getting a certain area using a certain transport mode of the existing transport network. The paper describes the concept of accessibility of the territory as a factor of sustainability of the urban transport system and methods of its assessment for urban conditions. It is proposed to use the indicator of the number of non-stop public transport routes between transport zones as a criterion for the "cost" of travel. Non-stop travel increases the comfort of public transport and reduces the financial costs of the passenger. The route network of the city of Lviv and interconnections of transport zones by public transport routes (bus, tram, and trolleybus) are analyzed. Modelling of passenger traffic volumes and their distribution by modes (private transport, public transport, and pedestrian traffic) was done in the PTV Visum software based on the matrix of a duration of movement and the matrix of the number of non-stop routes. It was found that at commensurate distances between transport zones, the number of non-stop routes increases the share of public transport users. The relationship between the number of non-stop routes and the share of public transport users is described by the logarithmic dependence. Comparing the simulated passenger flows on the public transport routes with the results of field researches, it was found that taking into account the number of non-stop routes between transport zones during the simulation allows increasing the accuracy of the results. Further research may focus on analyzing the impact of other factors that characterize the accessibility of the territory on the distribution of transport users between modes, and on the development of recommendations to the responsible city authorities to improve the city's passenger route network.
\end{abstract}

Keywords: transport system, route network, transport accessibility, transport modelling, transport modes.

\section{INTRODUCTION}

Sustainable development is a general ideology of human development in general and individual regions, which includes a set of measures aimed at improving the living standards of the population, taking into account the requirements of future generations.

The concept of sustainable development is based on three components: economic growth, social integration, and the environmental component (environmental protection). Regarding transport systems, the main problems from the point of view of assessing their sustainability are the problem of congestion, the problem of significant dependence on energy resources, and the problem of insufficient quality of transport infrastructure in many regions $[1,2]$.

Among the main criteria for the effectiveness of the transport system and the assessment of the convenience of transportation of the population are mobility, accessibility, network connectivity, and the level of transport discrimination [3]. Transport accessibility of the territory can be assessed by the 
possibility of reaching certain zones using a certain mode's choice of the existing transport network [3]. In fact, the availability indicator reflects the utility of the trip between two points, describing the complexity of this trip [4].

Accessibility is increasingly seen as one of the important criteria for assessing the level of integration of transport systems and improving the quality of transport services for passengers [5]. Accessibility of public transport is especially important in the design and evaluation of the transport system in terms of sustainability because the transition to public and non-motorized types of travel in the city is one of the key elements of sustainable urban mobility $[6,7]$.

\section{RESEARCH STATEMENT}

The authors [8] interpret the concept of accessibility as an opportunity for the passenger to choose the place of departure, mode choice, and route at each stage of planning and execution of the trip. This approach requires a shift from mobility-oriented transport planning to accessibility-oriented planning.

Modern literature often uses the concept of transport accessibility as a criterion for the efficiency of high-speed rail transport [9-11]. The authors note that the availability of high-speed rail significantly improves the attractiveness of the territory, contributing to its economic development and competitiveness. However, they warn of a possible negative effect for other areas, as the expansion of the high-speed railway network may lead to an increase in spatial imbalance.

Regarding the bus route network, among the latest scientific publications, it is worth noting the study [12], which assessed the availability of the Beijing bus network taking into account the intervals between vehicles, the number of routes, and the volume of traffic flows. The authors [13] consider the availability of transport zones as places of employment and studying on the example of Bogota. In addition to transport characteristics, the work also takes into account the structure of the population by average income.

The purpose of this paper is to assess the impact of transport accessibility of the territory on the distribution of trips of users of the urban transport system between the modes of movement in a large city (on the example of Lviv).

\section{ASSESSMENT OF THE IMPACT OF TRANSPORT ACCESSIBILITY OF LVIV ZONES ON THE DISTRIBUTION OF TRIPS BETWEEN MODES}

The most generalized expression for estimating availability $A_{i}$ was given by Koenig, who presents it as a function of the costs incurred by the user when performing the move [14]:

$$
A_{i}=\sum_{j} O_{j} \cdot f\left(C_{i j}\right),
$$

where $O_{j}$ - opportunities (utility or activity) to be gained from travelling to location $j ; C_{i j}-$ cost (time, financial, etc.) of travelling from location $i$ to location $j$.

In fact, to determine accessibility, you need to have information about the "cost" of moving between the origin and the destination zones for a particular user of transport services. The simplest indicator of the cost of travel is the distance you need to cover. However, the cost of travel is often a much broader concept, which may include the characteristics of the transport or route network, frequency, speed, comfort, financial, and time costs of travel [15].

System models of transport accessibility are based on accessibility matrices between individual points. Matrices can contain data on any type of travel costs (time, financial), can be balanced by data on the number or structure of the population [16].

The key elements in determining accessibility are the characteristics of the transport infrastructure, which not only provides the existing connections but also must have reserves to ensure the growing mobility of the population.

When traveling through the city, for most public transport users, the criterion for choosing a route is the non-stop trip. When you have to pay for each trip separately, this criterion is often more important than the distance or duration of travel. Therefore, when assessing the accessibility of urban zones in terms of 
public transport, it is advisable to take into account the number of possible alternative routes between each pair of transport zones.

Lviv route network consists of 7 tram routes, 10 trolleybus routes, 21 routes served by high-capacity buses, and 28 routes served by medium-capacity buses. There is no metro and other types of public transport in Lviv with a large carrying capacity, which suggests the equivalence of existing routes. For modeling in the PTV Visum software, the city territory was divided into 20 transport zones. Each zone is characterized by the origin and destination correspondences, which, respectively, are determined by the number of inhabitants in the zone and the number and volume of points of attractiveness for travel for different purposes (work, study, shopping, etc.) - Fig.1. To assess the interconnection of transport areas by the public transport network, we determined the number of routes passing through each transport zone and calculated a matrix of the number of non-stop routes connecting these zones (Fig. 2 and Table 1). This information is entered into the model as input data.

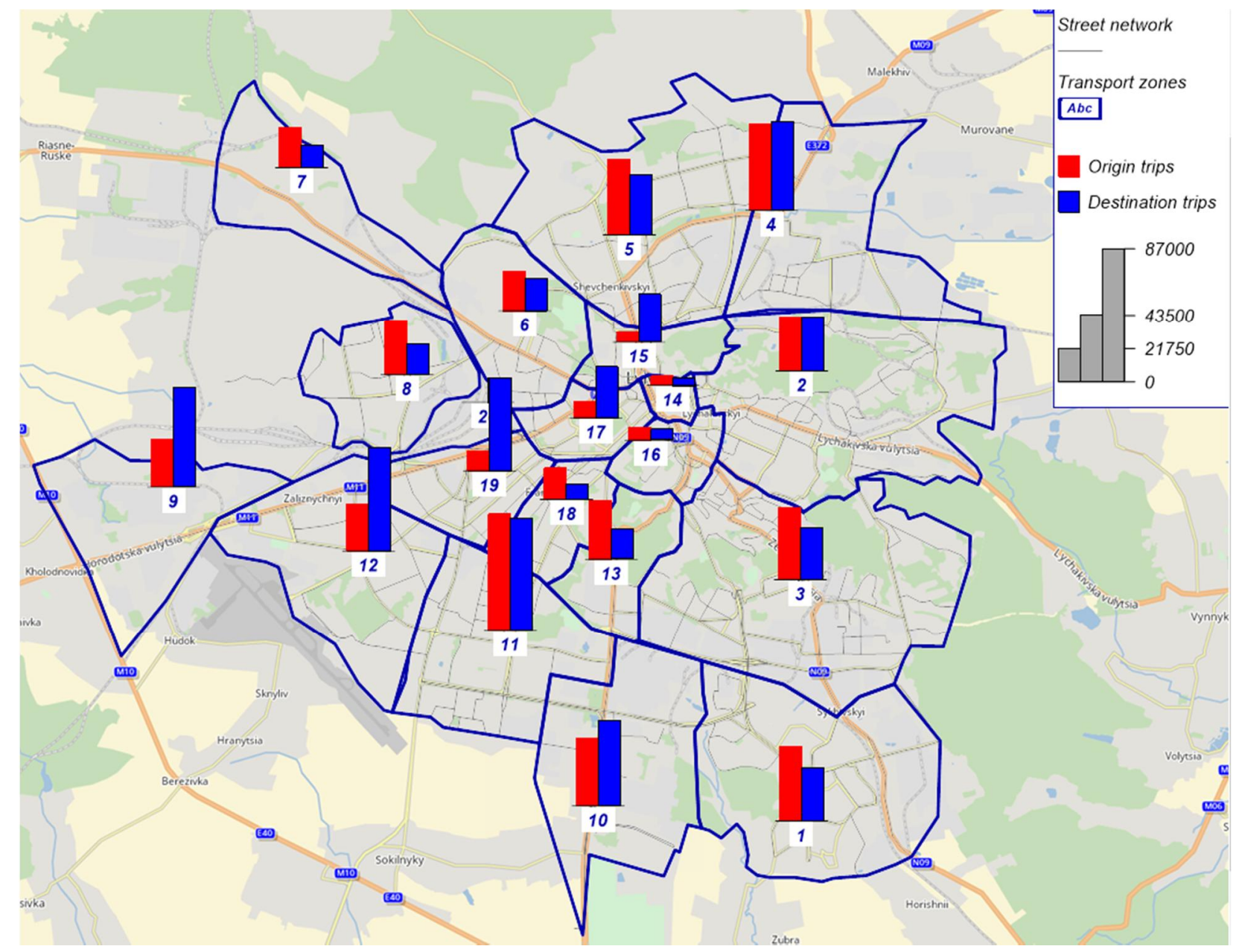

Fig. 1. Map of the transport zones of the Lviv city

The indicator of the number of routes per unit area $\left(\mathrm{km}^{2}\right)$ of the transport zones is also calculated. This indicator is the largest for the central zones of the city ( 31 public routes pass through the city center (transport zone $\mathrm{N} \mathrm{14),} \mathrm{from} 24$ to 30 routes pass through the 15,16,17, and 19 zones close to the center, the average value of the indicator is 18.4 routes $/ \mathrm{km}^{2}$ ), for other zones, it ranges from 0.36 to 4.19 .

Among the 190 pairs of transport zones under consideration, 38 do not have a direct connection by public transport routes $(20 \%)$. Another $16 \%$ of zones are connected by only one non-stop public transport route, $29 \%$ by two or three such routes, and $35 \%$ have more than three route options to travel between transport zones. 


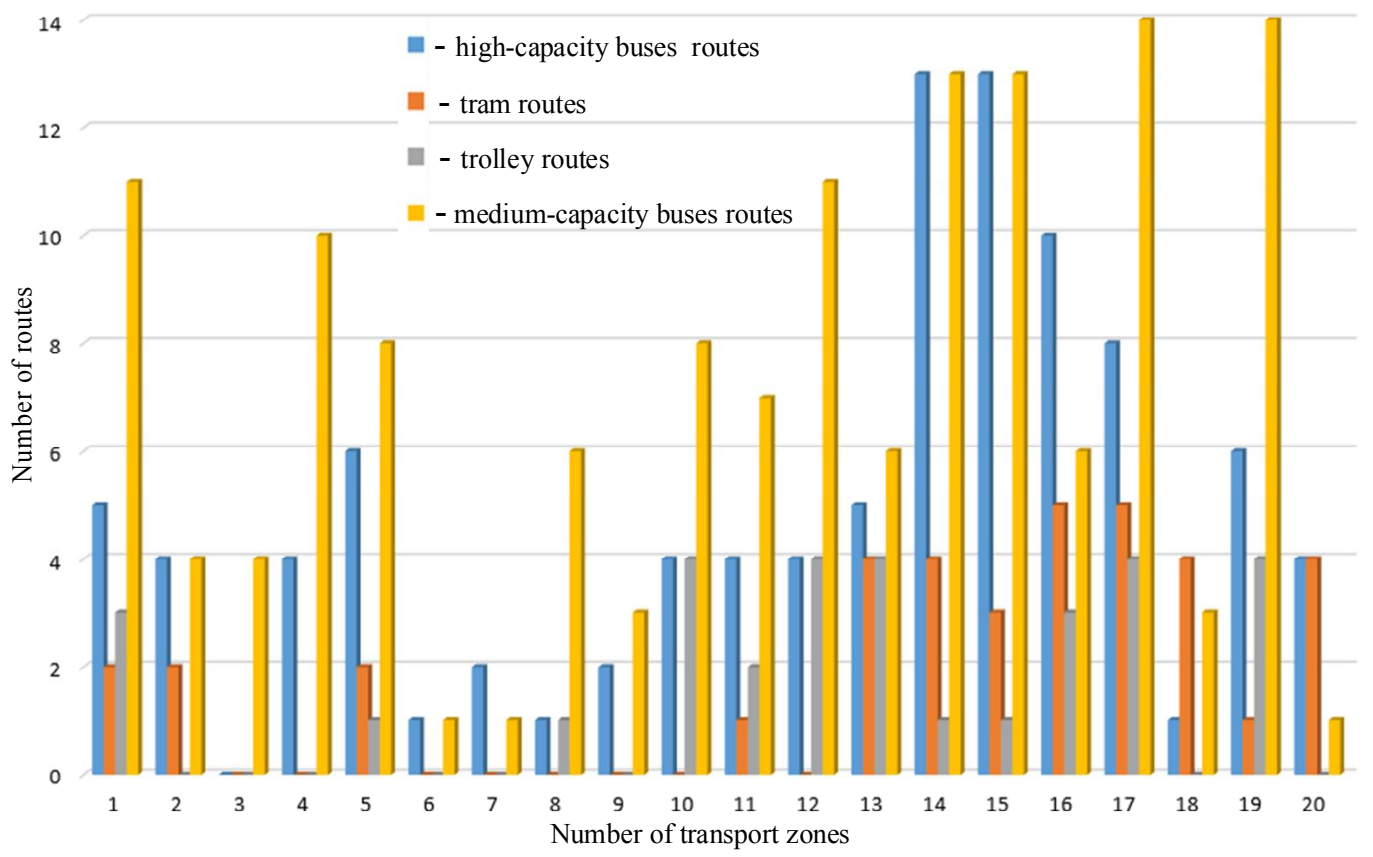

Fig. 2. Diagram of the number of routes that pass through the transport zones of Lviv

Table 1

Matrix of the number of non-stop public transport routes connecting pairs of transport zones of Lviv

\begin{tabular}{|r|r|r|r|r|r|r|r|r|r|r|r|r|r|r|r|r|r|r|r|r|}
\hline № & 1 & 2 & 3 & 4 & 5 & 6 & 7 & 8 & 9 & 10 & 11 & 12 & 13 & 14 & 15 & 16 & 17 & 18 & 19 & 20 \\
\hline 1 & - & 3 & & 4 & 5 & 1 & 2 & 1 & 1 & 9 & 6 & 7 & 6 & 6 & 6 & 8 & 5 & 3 & 6 & 3 \\
\hline 2 & 3 & - & & 1 & & & & 2 & & 2 & & 3 & 2 & 6 & 3 & 3 & 3 & 1 & 1 & 2 \\
\hline 3 & & & - & & & & & 1 & & & 1 & & 3 & 3 & 1 & 4 & 3 & 1 & 3 & \\
\hline 4 & 4 & 1 & & - & 5 & & & 2 & 1 & 3 & 2 & 3 & 1 & 11 & 12 & 3 & 8 & 2 & 7 & 1 \\
\hline 5 & 5 & & & 4 & - & 2 & 1 & 2 & 1 & 1 & 2 & 2 & 1 & 12 & 16 & 3 & 4 & 2 & 5 & 3 \\
\hline 6 & 1 & & & & 2 & - & 1 & 1 & & & & & & 2 & 2 & 1 & & & & \\
\hline 7 & 2 & & & & 1 & 1 & - & & & 1 & 1 & 1 & & 2 & 2 & 2 & 1 & & 1 & \\
\hline 8 & 1 & 2 & 1 & 2 & 2 & 1 & & - & & 1 & 2 & 3 & 3 & 4 & 3 & 2 & 4 & & 4 & \\
\hline 9 & 1 & & & 1 & 1 & & & & - & 1 & 1 & 5 & & 2 & 2 & 1 & 4 & & 3 & \\
\hline 10 & 9 & 2 & & 3 & 1 & & 1 & 1 & 1 & - & 5 & 7 & 2 & 4 & 5 & 3 & 6 & 2 & 7 & 2 \\
\hline 11 & 6 & & 1 & 2 & 2 & & 1 & 2 & 1 & 5 & - & 8 & 5 & 4 & 3 & 6 & 6 & 3 & 4 & 1 \\
\hline 12 & 7 & 3 & & 3 & 2 & & 1 & 3 & 5 & 7 & 8 & - & 4 & 5 & 4 & 2 & 9 & & 10 & 2 \\
\hline 13 & 6 & 2 & 3 & 1 & 1 & & & 3 & & 2 & 5 & 4 & - & 6 & 3 & 11 & 5 & 5 & 4 & 3 \\
\hline 14 & 6 & 6 & 3 & 11 & 12 & 2 & 2 & 4 & 2 & 4 & 4 & 5 & 6 & - & 25 & 16 & 18 & 5 & 14 & 5 \\
\hline 15 & 6 & 3 & 1 & 12 & 16 & 2 & 2 & 3 & 2 & 5 & 2 & 4 & 1 & 25 & - & 11 & 15 & 3 & 11 & 4 \\
\hline 16 & 8 & 3 & 4 & 3 & 3 & 4 & 2 & 2 & 1 & 3 & 6 & 2 & 11 & 16 & 11 & - & 10 & 6 & 6 & 2 \\
\hline 17 & 5 & 3 & 3 & 8 & 4 & & 1 & 4 & 4 & 6 & 6 & 9 & 3 & 18 & 15 & 10 & - & 7 & 22 & 6 \\
\hline 18 & 3 & 1 & 1 & 2 & 2 & & & & & 2 & 3 & & 5 & 5 & 3 & 6 & 7 & - & 4 & 2 \\
\hline 19 & 6 & 1 & 3 & 7 & 5 & & 1 & 4 & 3 & 7 & 4 & 10 & 4 & 14 & 11 & 6 & 22 & 4 & - & 3 \\
\hline 20 & 3 & 2 & & 1 & 3 & & & & & 2 & 1 & 2 & 3 & 5 & 4 & 2 & 6 & 2 & 3 & - \\
\hline
\end{tabular}

For modelling, the daily number of public transport trips in urban areas uses a four-stage model of transport demand [9]. To use it in PTV Visum, you need to perform the following basic procedures:

- procedure "Trip generation": in that stage, for each transport zone and each demand stratum, the origin and destination correspondence are calculated. Production of transport zone is calculated with the help of formula [17]: 


$$
Q_{i}=\sum_{g} a_{g} \cdot S \cdot G_{g}(i)
$$

where $a_{g}$ - the coefficient, a production rate that shows a number of trips per structural property unit; $S \cdot G_{g}(i)$ - the number of inhabitants of a zone $i$.

The attractiveness of the transport zone $\left(Z_{j}\right)$ is similarly determined (based on the characteristics of the points of attractiveness).

- procedure "Trip distribution": in that stage, the elements of the demand matrix for each demand stratum using a gravity model are calculated:

$$
F_{i j}=k_{i j} \cdot Q_{i} \cdot Z_{j} \cdot f\left(U_{i j}\right)
$$

where $k_{i j}$ - attractiveness factor for OD pair zone $i$ to zone $j ; f\left(U_{i j}\right)$ - value for the utility between zones.

The utility function may take the form Logit, Kirchhoff, BoxCox, Combined, or TModel.

- procedure "Mode choice": breaks down the total demand into the transport modes (private transport, public transport) based on mode-specific impedance skims.

The Logit function has the form:

$$
f\left(U_{i j}\right)=e^{c \cdot U_{i j}} .
$$

Usually, the value of the utility is distance or travel time. However, when moving by public transport, the number of routes connecting each pair of transport zones is important. Therefore, the inverse matrix of the number of routes is used as a cost matrix for the public transport mode.

- procedure "public transport assignment": in that stage, the matrices of correspondence received at the third stage are distributed on routes of public transport.

As a result of modelling, the distribution of trips from each transport zone on modes is received: private transport, public transport, and walk or by bicycle. That is, in particular, 190 values of the share of public transport users were obtained. The analysis of the obtained results (example - Fig. 3) showed that at commensurate distances between zones, the increase in the number of routes connecting them affects the redistribution of passenger traffic between modes (increasing the share of public transport users).

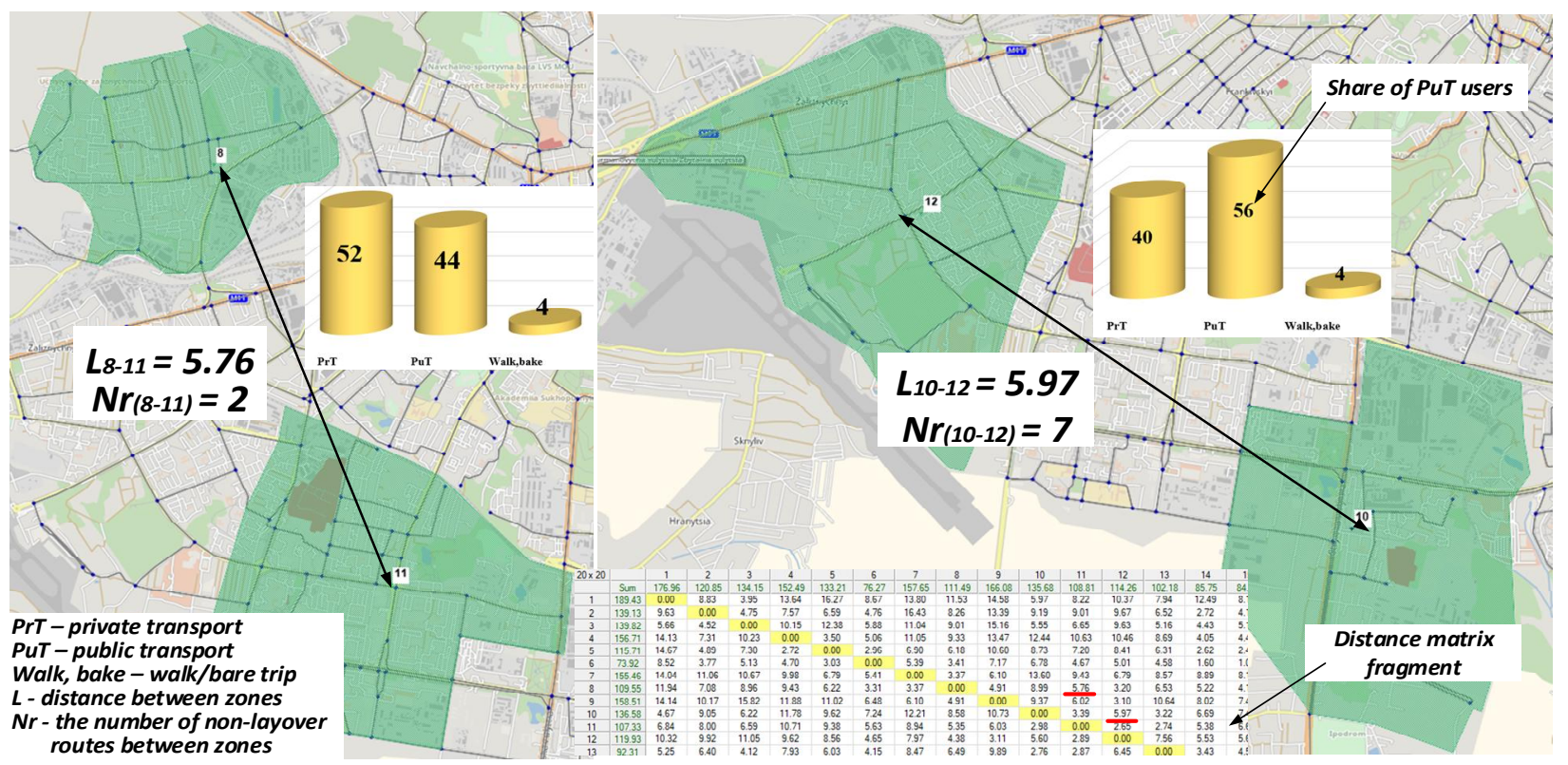

Fig. 3. Comparison of changes between modes choice for pairs of transport zones

Fig. 4 shows the graphical relationship between the number of non-stop routes connecting a couple of zones of origin and the destination of the trip and the percentage increase in the number of users of public transport. The dependence is described by a logarithmic curve with a coefficient of determination equal to 0.93 . As the number of routes increases from 0 to 15 , the number of public transport users 
increases by $20 \%$. Further increase in the number of routes already has a negligible effect on the growth of the share of public transport volume: with the increase in the number of routes from 15 to 25 , the share of public transport users increases by $4 \%$, and from 25 to 35 - by $2 \%$.

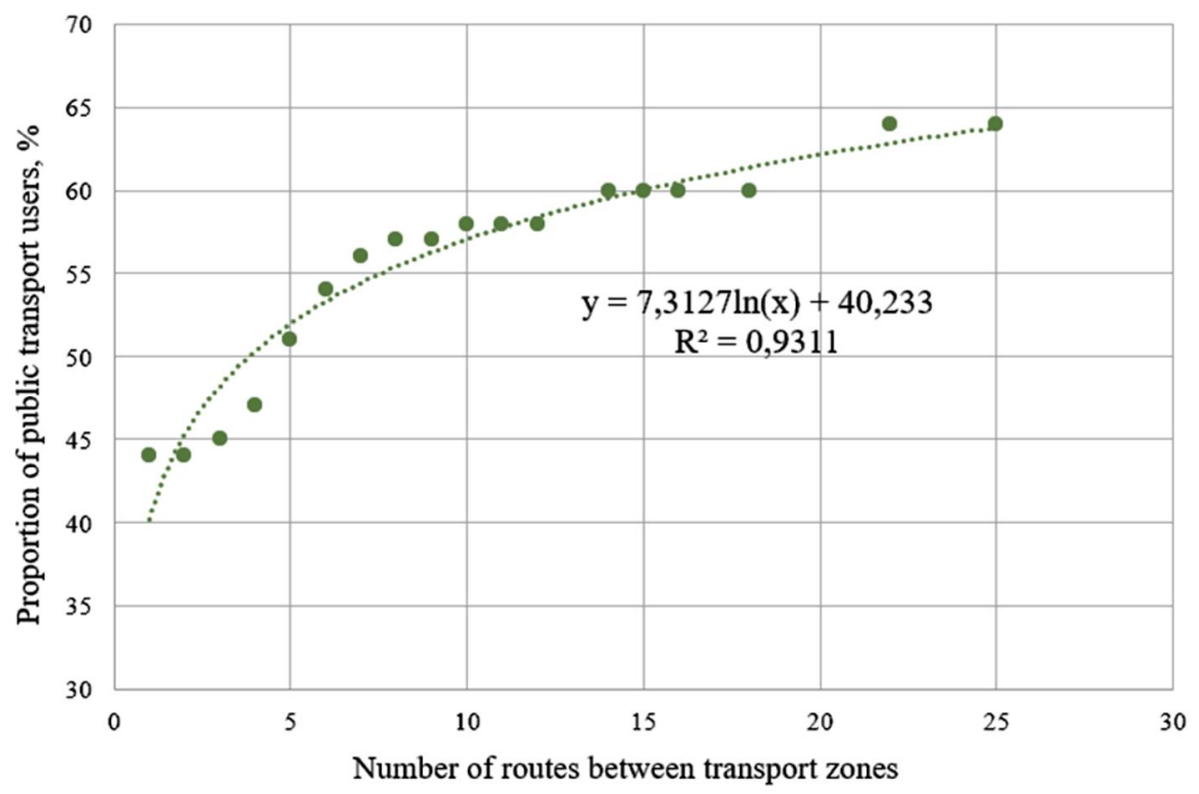

Fig. 4. Relationship between the number of non-stop routes between transport zones and the share of users who use public transport to trip between them

As a result of the fourth stage of modelling using PTV Visum, we have both the general distribution of passenger flows through the network and the average values of passenger traffic per turn-around on each of the routes of public transport.

To assess the feasibility of using the matrix of the number of routes as a cost matrix for public transport, simulation of the distribution of passenger flows based on the matrix of travel time, but with all other parameters, which are the same, was carried out.

To analyze the obtained simulation results, field researches were conducted on two trolleybus routes (\# 32 and \# 29), two tram routes (\# 3 and \# 6), and four bus routes (\#\# 10, 18, 47A, and 52). Field researches on each of the routes were conducted during the peak period of working days of the week. The results of these researches for bus route \# 18 are presented in Fig. 5.

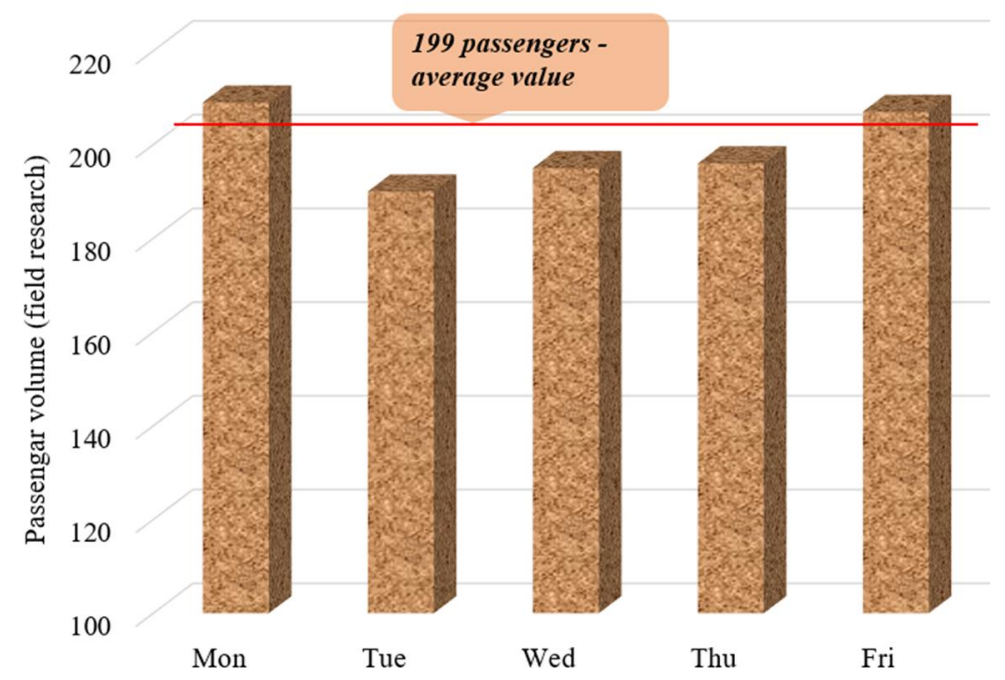

Fig. 5. The results of field research of passenger traffic on the public route \#18 
The obtained simulation results based on the matrix of the number of routes between transport zones, the matrix of the duration of the trip between the transport zones, and the data of field researches are presented in Table 2 .

Table 2

\section{Comparison of the results of field researches and modelling of passenger flows in PTV Visum}

\begin{tabular}{|c|c|c|c|c|}
\hline \multirow{2}{*}{ Route number } & $\begin{array}{c}\text { The route } \\
\text { turn-around } \\
\text { time, min }\end{array}$ & \multicolumn{2}{|c|}{ The passenger volume on the route per turn-around time, obtained as a result } \\
\cline { 4 - 5 } & $\begin{array}{c}\text { field research } \\
\text { (average mean) }\end{array}$ & $\begin{array}{c}\text { modelling } \\
\text { (number of route matrix) }\end{array}$ & $\begin{array}{c}\text { modelling } \\
\text { (travel time matrix) }\end{array}$ \\
\hline Trolley \# 29 & 47 & 176 & 180 & 205 \\
\hline Trolley \# 32 & 50 & 186 & 165 & 185 \\
\hline Tram \# 3 & 45 & 249 & 264 & 280 \\
\hline Tram \# 6 & 55 & 218 & 225 & 241 \\
\hline Bus \# 10 & 85 & 142 & 134 & 218 \\
\hline Bus \# 18 & 130 & 199 & 206 & 225 \\
\hline Bus \# 47A & 163 & 202 & 213 & 200 \\
\hline Bus \# 52 & 136 & 180 & 191 & \\
\hline
\end{tabular}

The comparison of the obtained results shows that the modelling of passenger flows on public transport routes, taking into account the data on the number of non-stop routes, gives values that are closer to the results of field researches.

\section{CONCLUSIONS AND RESEARCH PERSPECTIVES}

One of the criteria for the sustainability of the city's transport system is to minimize the use of a private car for daily trips in the city. That is, the larger the share of public transport users in the overall structure of traffic, the more sustainable is the city transport system. The distribution of trips between modes depends, in particular, on the accessibility of transport zones. This study was conducted to determine the impact of the availability of transport zones on the distribution of trips in Lviv. As a criterion of accessibility, it is proposed to take into account, in addition to the duration of travel, the number of nonstop routes of public transport.

The study found that the number of such routes affects the share of public transport users: with commensurate travel times, the increase in the percentage of public transport travels is logarithmic. The growth of the share of public transport users in the range of changes in the number of non-stop routes from 0 to 15 is particularly active.

The results of modelling (in the PTV Visum software environment) of passenger traffic on separate routes of public transport with the results of field researches on these routes were also compared. Modelling, using as a matrix of cost data on the number of routes, gives results that are closer to the results of field researches compared to the results of modelling only based on the matrix of travel time by public transport. The obtained results show that taking into account the number of non-stop routes between the transport zones of the city during the modelling of passenger flows increases the accuracy of such modelling.

Further research may be aimed at studying the impact of other parameters of accessibility of transport zones on the distribution of trips between modes.

\section{References}

1. Buryk, M. (2020). Upravlinnia rozvytkom transportnoi infrastruktury v umovakh realizatsii hlobalnykh tsilei staloho rozvytku do $2030 \mathrm{r}$. [Management of transport infrastructure development in the context of the implementation of the global sustainable development goals by 2030]. Theory and Practice of Public Administration, 4(71), 55-62. doi:10.34213/tp.20.04.07 (in Ukrainian).

2. Zhao, X., Ke, Y., Zuo, J., Xiong, W., \& Wu, P. (2020). Evaluation of sustainable transport research in 2000-2019. Journal of Cleaner Production, 256. doi: 10.1016/j.jclepro.2020.120404 (in English). 
3. Pashynska, N. (2013). Novi pidkhody do doslidzhennia transportnoi dostupnosti v heohrafii transportu [New approaches to the study of transport accessibility in the geography of transport]. Heohrafichna nauka $i$ praktyka: vyklyky epokhy: Materialy mizhnarodnoi naukovoi konferentsii, 147-150 (in Ukrainian).

4. Handy, S. L., \& Niemeier, D. A. (1997). Measuring accessibility: an exploration of issues and alternatives. Environment and planning A, 29(7), 1175-1194. doi: 10.1068/a291175 (in English).

5. Matiichyk, O. M. (2017). Efektyvnist dostupnosti transportnoi merezhi na prykladi Stolychnoho ekonomichnoho raionu [Network efficiency accessibility on the case of Capital economic region]. Molodyi vchenyi, (4), 552-555. (in Ukrainian).

6. Saif, M. A., Zefreh, M. M., \& Torok, A. (2019). Public transport accessibility: a literature review. Periodica Polytechnica Transportation Engineering, 47(1), 36-43. doi: 10.3311/PPtr.12072 (in English).

7. Makarova, I., Pashkevich, A., Shubenkova, K., \& Mukhametdinov, E. (2017). Ways to increase population mobility through the transition to sustainable transport. Procedia Engineering, 187, 756-762. doi: 10.1016/j.proeng.2017.04.434 (in English).

8. Yang, C., \& He, S. (2010). An accessibility measure for the combined travel demand model. Science China Information Sciences, 53(2), 299-306. doi: 10.1007/s11432-010-0006-z. (in English).

9. Monzón, A., Ortega, E., \& López, E. (2013). Efficiency and spatial equity impacts of high-speed rail extensions in urban areas. Cities, 30, 18-30. doi: 10.1016/j.cities.2011.11.002 (in English).

10. Kim, H., \& Sultana, S. (2015). The impacts of high-speed rail extensions on accessibility and spatial equity changes in South Korea from 2004 to 2018. Journal of Transport Geography, 45, 48-61. doi: 10.1016/j.jtrangeo.2015.04.007 (in English).

11. Shaw, S. L., Fang, Z., Lu, S., \& Tao, R. (2014). Impacts of high speed rail on railroad network accessibility in China. Journal of Transport Geography, 40, 112-122. doi: 10.1016/j.jtrangeo.2014.03.010 (in English).

12. Yu, W. T., Zhang, K., Li, J., Sun, H. J., \& Qu, Y. C. (2020). Urban public transport network accessibility based travel data. Journal of Transportation Systems Engineering \& Information Technology, 20(4), 106-112. doi: 10.16097/j.cnki.1009-6744.2020.04.016 (in English).

13. Guzman, L. A., Oviedo, D., \& Rivera, C. (2017). Assessing equity in transport accessibility to work and study: The Bogotá region. Journal of Transport Geography, 58, 236-246. doi: 10.1016/j.jtrangeo.2016.12.016 (in English).

14. Miller, H. J. (1999). Measuring space-time accessibility benefits within transportation networks: Basic theory and computational procedures. Geographical analysis, 31(1), 187-212. doi: 10.1111/gean.1999.31.1.187 (in English).

15. Ford, A. C., Barr, S. L., Dawson, R. J., \& James, P. (2015). Transport accessibility analysis using GIS: Assessing sustainable transport in London. ISPRS International Journal of Geo-Information, 4(1), 124-149. doi: 10.3390/ijgi4010124 (in English).

16. Rietveld, P., \& Bruinsma, F. (2012). Is transport infrastructure effective? Transport infrastructure and accessibility: impacts on the space economy. Springer Science \& Business Media. 383 p. doi: 10.1007/978-3-64272232-5 (in English).

17. PTV Vision: VISUM 11.5 Basics. (2010). Karlsruhe: PTV AG. 756 p. (in English).

Received 26.08.2021; Accepted in revised form 28.09.2021.

\section{ОЦІНКА СТАЛОСТІ ТРАНСПОРТНОЇ СИСТЕМИ МІСТА ЛЬВОВА ЗА КРИТЕРІЕМ ДОСТУПНОСТІ}

Анотація. Транспортна доступність території визначає можливість досягнення певної ділянки з використанням певного режиму переміщення наявною транспортною мережею. У роботі охарактеризовано поняття доступності території як чинника сталості міської транспортної системи та способи їі очінки для міських умов. Запропоновано використання показника кількості безпересадкових маршрутів громадського транспорту (ГТ) 
між транспортними районами як критерію “вартості" переміщень. Безпересадковість поїзки підвищує комфорт подорожі громадським транспортом та зменшує фінансові витрати пасажира. Проаналізовано маршрутну мережу міста Львова та взаємозв'язки транспортних районів маршрутами громадського транспорту (автобусними, трамвайними та тролейбусними). Проведено моделювання обсягів пасажиропотоків та їх розподілу за режимами (приватний транспорт, громадський транспорт $і$ рух пішки) в програмному середовищі PTV Visum на основі матриці тривалості переміщення та матриці кількості безпересадкових маршрутів. Виявлено, що за співмірних відстаней між транспортними районами кількість безпересадкових маршрутів збільшує частку користувачів громадського транспорту. Зв'язок між кількістю безпересадкових маршрутів та часткою користувачів ГТ описується логарифмічною залежністю. Порівнянням змодельованих пасажсиропотоків на маршрутах ГТ з результатами натурних обстежень, виявлено, що врахування кількості безпересадкових маршрутів між транспортними районами під час моделювання дає змогу збільшити точність отриманих результатів. Подальші дослідження можуть бути спрямовані на аналіз впливу інших чинників, які характеризують доступність території, на розподіл користувачів транспорту між режимами, та на розробку рекомендачій відповідальним органам міського управління щодо вдосконалення міської пасажирської маршрутної мережі.

Ключові слова: транспортна система, маршрутна мережа, транспортна доступність території, моделювання транспорту, режими переміщення. 